\title{
Understanding the Effect of the COVID-19 Pandemic on Management Accounting Students
}

\author{
Sharon Zunckel ${ }^{1}$, Mbali Portia Msomi ${ }^{1}$, Stephanie Caroline Samuel ${ }^{2} \&$ Ferina Marimuthu $^{2}$ \\ ${ }^{1}$ Management Accounting Department, Durban University of Technology, Durban, South Africa \\ ${ }^{2}$ Financial Accounting Department, Durban University of Technology, Durban, South Africa \\ Correspondence: Ferina Marimuthu, Financial Accounting Department, Durban University of Technology, Durban, \\ South Africa.
}

Received: November 10, 2021

Accepted: December 20, 2021

Online Published: December 28, 2021

doi:10.5430/ijhe.v11n3p130

URL: https://doi.org/10.5430/ijhe.v11n3p130

\begin{abstract}
A switch to emergency remote teaching, learning, and assessment (TLA) has become necessary as a result of the social distancing brought about by the recent COVID-19 pandemic. Higher Education Institutions (HEIs) were forced to switch from face-to-face to online teaching and learning to ensure successful completion of the academic year as well as the safety of their staff and students from a global pandemic. This arrangement has created teaching problems in terms of familiarizing oneself with technology, losing face-to-face contact, and limiting access to essential facilities such as laboratories and libraries. The new normal is when remote learning is employed to fulfil TLA obligations. Therefore, students are expected to adjust from a traditional to a remote learning environment. This change in environment highlights the importance of exploring students' perceptions as the recipients of this novel learning. Hence, the aim of this study was to explore the impact that the COVID-19 pandemic has had on student learning, underpinned by the activity theory. Quantitative research methods were applied to elicit students' perceptions of remote learning through the use of an online questionnaire. The target population comprised undergraduate management accounting students. The paper provides interesting implications for government, policymakers, regulatory bodies, and other researchers because it offers a student perspective on the challenges experienced with remote learning.
\end{abstract}

Keywords: COVID-19, online learning, blended learning, face-to-face learning

\section{Introduction}

Globally, this world is facing an unprecedented challenge in dealing with the recent COVID-19 pandemic. Although these remain uncertain times, the virus's rapid spread has had traumatic and dramatic impacts on everyone. In South Africa, the president announced a national lockdown on March 26, 2020, to protect lives and contain the spread of the virus. Among the affected sectors, higher education institutions (HEIs) had to close with immediate effect due to the COVID-19 pandemic. Considering the pandemic's new social distancing rules, HEIs were forced to adopt remote teaching, learning, and assessment (TLA) methods to ensure successful completion of the 2020 academic year (Adnan \& Anwar, 2020; Malhotra \& Bhatia 2021; Wintachai et al., 2021). There was a shift in the academic role emphasized amid the pandemic with the closure of the education sector globally. This decision caught academics off guard, resulting in teaching problems in terms of familiarizing oneself with technology, loss of face-to-face contact, and access to essential facilities such as laboratories and libraries. Likewise, students had to transition from face-to-face to remote learning as part of continuity plans for the academic programmes during the lockdown. These uncharted territories required emergency planning and prompt decision-making on curricula, pedagogies, and assessments for remote teaching and learning (Ali, 2020; Laksana, 2021). As a result, academics had to become more resilient and adaptive toward these extraordinary changes in the learning environment. Learning management systems (LMSs) have been brought to the forefront of TLA by academics, especially with HEIs exploring LMSs that provide solutions during the lockdown period. This also precipitated challenges for students (Abbasi et al., 2020). Online learning had its weaknesses, including social isolation, lack of one-on-one consultation, and network issues, which cannot be ignored (Abbasi et al., 2020). Although many universities offer face-to-face lectures and online learning, the recent COVID-19 pandemic has forced these higher learning institutions to invest more in online teaching and learning. HEIs had to develop or revise existing plans to ensure that the academic programme could continue to adopt digital teaching and learning methods impacting all stakeholders. 
The COVID-19 pandemic has affected people regardless of nationality, level of education, income, or gender. The impact of its consequences was such that the most vulnerable have been hit the hardest, especially the education sector. When the HEIs closed their doors and explored alternative means of TLA, students from privileged backgrounds who had the support of their parents could find their way when their institutions closed the doors. However, those learners that came from disadvantaged backgrounds often remained shut out when their institutions were shut down (Schleicher, 2020). The pandemic has exposed the many inadequacies and inequalities in our educational system - from access to the broadband and devices required for online TLA and the supportive environments necessary to focus on learning to the misalignment between resources and needs.

This paper addresses the abovementioned research gap, which became the impetus for exploring students' perceptions rather than those of the academics because the students are the recipients of this novel learning. Moreover, academics have the sole responsibility of providing a conducive learning environment that will provide effective online learning solutions. Hence, the study explored the challenges experienced by the management accounting course learners at Durban University of Technology (DUT) during the onset of the COVID-19 pandemic.

\section{Literature Review}

\subsection{COVID-19 Repercussions}

The coronavirus outbreak, commonly referred to as COVID-19 and labelled a pandemic by the World Health Organization, has impacted the world. This respiratory virus was first identified in Wuhan, China, and then rapidly spread to most parts of the world. The outbreak spread to South Africa, with the first confirmed case announced by the minister of health on March 5, 2020. Less than 2 weeks later, the South African president declared a national state of disaster. Preventive measures announced included the closure of schools and universities immediately thereafter. The pandemic has laid bare the digital divide between those HEIs with a better information and communications technology (ICT) infrastructure than others. Some are far better equipped and experienced than others. The closure of HEIs and the implementation of social distancing regulations has led to educational institutions experimenting on ways to complete the syllabus within the allotted period. According to Muthuprasad et al. (2020), online learning can be effective if students have access to the internet, devices, and software necessary to optimize students' learning experience. In addition, the authors iterated that online classes should be well structured, concise, interactive, and relevant; lecturers must invest time in designing the content. However, online learning is not without challenges, and the study identified technological constraints as one of the greatest challenges. Other challenges identified included lack of access to the internet, slow connections, the lack of community, and the lecturer's incompetence.

\subsection{Face-to-Face Teaching versus Remote Teaching}

Traditionally, TLA has taken place via face-to-face interaction in a learning environment. Doing this allowed real-time lecturer-student interaction to resolve any queries, administer assessments, provide feedback, and learn within a controlled environment. Face-to-face learning is considered to be superior to an online and blended mode of TLA. Online learning has come to the forefront of teaching and learning during the 2020 COVID-19 pandemic; however, most higher learning institutions are not fully equipped to manage online learning at the required level. According to the World Bank (2020a), an effective online TLA necessitates infrastructure, tools, and hardware and software systems that meet the objective of the higher learning institution. In 2020 there was a rapid integration of ICT within these institutions, with some institutions introducing LMSs such as Moodle, Blackboard, and Microsoft (MS) Teams, while other institutions who have already implemented these LMSs in previous years are now entirely relying on the LMSs to deliver the course content. The practices involved in designing and implementing face-to-face TLA activities are very different from those suited to remote TLA, where the lecturer and students are separated in terms of time and distance (see Table 1). 
Table 1. Face-face and virtual teaching conditions

Table 1: Face-face and virtual teaching conditions

\begin{tabular}{|c|c|c|c|c|}
\hline & \multicolumn{2}{|c|}{ Face-to-face teaching conditions } & \multicolumn{2}{|c|}{ Virtual teaching conditions } \\
\hline & $\begin{array}{c}\text { In class } \\
\text { (in real time) }\end{array}$ & $\begin{array}{c}\text { Out of class } \\
\text { (At your own pace) }\end{array}$ & $\begin{array}{l}\text { Synchronous } \\
\text { (In real time) }\end{array}$ & $\begin{array}{c}\text { Asynchronous } \\
\text { (at your own pace) }\end{array}$ \\
\hline Present content & $\begin{array}{l}\text { Lecture } \\
\text { Demonstrations }\end{array}$ & Readings & $\begin{array}{l}\text { Virtual Lectures } \\
\text { Virtual } \\
\text { Dernonstrations }\end{array}$ & $\begin{array}{l}\text { Readings } \\
\text { Recorded lectures, } \\
\text { videos, screencasts, } \\
\text { simulations }\end{array}$ \\
\hline $\begin{array}{l}\text { Engage } \\
\text { students in } \\
\text { Learning } \\
\text { Activities }\end{array}$ & $\begin{array}{l}\text { Tutorials } \\
\text { Practical's } \\
\text { White board } \\
\text { sessions }\end{array}$ & $\begin{array}{l}\text { Group work } \\
\text { Projects } \\
\text { Assignments }\end{array}$ & $\begin{array}{l}\text { Live presentations } \\
\text { Virtual group } \\
\text { discussions } \\
\text { Virtual break-out } \\
\text { rooms }\end{array}$ & $\begin{array}{l}\text { Online discussion } \\
\text { forums } \\
\text { Online annotation } \\
\text { tools } \\
\text { Google docs, blogs }\end{array}$ \\
\hline $\begin{array}{l}\text { Bulld } \\
\text { Communication } \\
\text { \& Community }\end{array}$ & $\begin{array}{l}\text { Groups } \\
\text { Discussion }\end{array}$ & $\begin{array}{l}\text { Email } \\
\text { Office } \\
\text { hours/ } \\
\text { consults }\end{array}$ & $\begin{array}{l}\text { Online chat \& live } \\
\text { discussions } \\
\text { Virtual office hours } \\
\text { Twitter chat, social } \\
\text { media }\end{array}$ & $\begin{array}{l}\text { Email } \\
\text { Online discussion } \\
\text { forums } \\
\text { Online Q\&A }\end{array}$ \\
\hline $\begin{array}{l}\text { Conduct } \\
\text { Assessment }\end{array}$ & $\begin{array}{l}\text { Quizzes } \\
\text { Exams } \\
\text { Presentations }\end{array}$ & $\begin{array}{l}\text { Essays } \\
\text { Reflection journals } \\
\text { Projects }\end{array}$ & $\begin{array}{l}\text { Virtual } \\
\text { presentations }\end{array}$ & $\begin{array}{l}\text { Quizzes, } \\
\text { Assignments, } \\
\text { Reflection journals, } \\
\text { Projects }\end{array}$ \\
\hline
\end{tabular}

Source: DUT (2020)

Besides acquainting oneself with the online platforms, remote TLA involves deciding what knowledge is selected and how it will be sequenced and paced for remote teaching. It also involves choices about pedagogies and assessments and their alignment to the intended learning outcomes for modules.

Online learning requires data for both lecturer and student in order to attain proper online training, digital content preparation, student engagement across various digital platforms, and responses to student queries regarding issues accessing online classrooms, consultations, and student support. Students can access this platform at any time because there are no restrictions regarding consultations and queries. For students to benefit fully from online learning, necessary technology such as laptops and smartphones, as well as data and log-in access to classrooms, needs to be made available. With the shift from face-to-face to remote online learning, a lack of orientation and training could lead to challenges. The students need to be competent to navigate the online learning platform (Agormedah et al., 2020).

Despite the growing need for institutions to utilize the LMSs to support TLA, student and staff readiness and access to hardware must be considered. Students of this generation are more exposed to technology than previous generations were, with devices such as desktops, laptops, mobile devices, and tablets accessible in the technology market (Ali, 2020). However, some of these technological devices, such as laptops and desktop computers, are not found in many households. Higher learning institutions must ensure that TLA can be accessed on mobile devices and tablets (World Bank, 2020a). The World Bank (2020a) proposed that HEIs partner with network providers. Hence, the South African government partnered with the leading network operators to provide zero-rated applications and educational websites (Mhlanga \& Moloi, 2020). The authors further noted that data traffic during the lockdown escalated to $60 \%$ across all networks; however, among students in different countries, access to the internet proved to be a common challenge. While noting this challenge, DUT entered into a partnership with all network operators in South Africa to provide data to staff and students during the lockdown. In addition to the technological importance, another key point is the support of families, which plays a central role in supporting students in their learning. The World Bank (2020b) reckoned that parents and guardians might be ill equipped to help their children, which could be due to a lack of technological savviness, multiple children in the household to support, and having to allocate devices and bandwidth among siblings. 


\subsection{Theoretical Framework}

The activity theory (AT) by Karasavvidis (2009) was reviewed as the underpinning theory for this study. This framework enables the systematic study of innovation in an online learning context and is a helpful tool used in the education sector when a major innovation such as blended learning is introduced. In addition, because the AT is implemented as a theoretical framework in the analyses of technologically augmented academic programmes (Barab et al., 2002; Scanlon \& Issroff, 2005), it allows for the conceptualization of what works and what does not in innovation. Additionally, it helps to identify what impedes change and at what level and concerning which factors. The AT was applied to understand better the impact of blended learning on a group of newly exposed learners. The AT identifies areas of tension such as struggles, resistance, ambiguities, and discrepancies within the concept of a given system. Before the COVID-19 pandemic, Moodle was the LMS that was introduced for blended learning at the DUT. Students were unfamiliar with MS Teams, an additional LMS introduced during the national lockdown. Karasavvidis (2009) stated that what to learn and how to learn, within rules and division of labour, are the areas of tension identified. Furthermore, the AT is also a tool used to understand the reconfiguration of practice resulting from the innovation introduced.

\subsection{Prior Research Studies}

To address the aim of this study, I conducted an empirical review of the literature; more specifically, I reviewed the relevant literature online and the blended TLA focused on student perceptions.

Owston et al. (2019) conducted research that examined how students perceive blended learning at public universities. Blended learning is attributed to integrating online learning with contact-based learning. A few of the pertinent factors that Owen et al. studied were student satisfaction and interaction with blended learning TLA methods. The study highlights the fact that student interaction is essential to academic achievement. Most respondents viewed the blended TLA methods that were introduced favourably, with reasons such as the coursework being available and accessible at the students' convenience. Essentially, the availability and access to recorded lectures proved beneficial to most passive learners, a benefit that cannot be attributed to traditional contact-based TLA courses.

Larkin (2019) observed students' perceptions of online and blended computer courses using two sample groups at a community college. The groups, classified as fully online and hybrid (blended), were made up of 20-year-old students. The study assumed that because this group of students was born in the age of technology, the transition to online learning would be smooth. This is attributed to millennials being born in a technologically savvy era, opining that younger students are more adaptable than older students. The study examined student interaction and activity for the online and blended courses. The findings of the study found that online TLA is less interactive than blended TLA. However, student activity was more dominant in the online course, which was attributed to students being forced to adopt responsibility, independence, self-motivation, and accountability. However, it is important to note that the students included in the study indicated their preferred method of TLA to be either online or blended. The study also found that instructor interaction and availability play a vital role in student interaction in online and blended courses.

Giovannella (2021) conducted a study on 101 students in a bachelor's in science education program at an Italian university to understand the effects of switching from the traditional face-to-face class to a virtual space during the COVID-19 pandemic. The main findings indicated that the move to a complete virtual setting was positively absorbed despite students missing physical contact. The study also found that most students are ready for novel educational processes grounded in a blended learning approach. However, this was not the case for the study conducted by Owusu-Fordjour et al. (2020), who investigated the challenges of COVID-19 on Ghana's educational system, particularly examining the challenges students faced in learning. The study followed a quantitative approach utilizing a structured questionnaire as the research instrument. The study revealed that homes in Ghana do not have access to the internet, and those who were found to have internet access could not fully utilize online learning due to the high cost of a data bundle. Furthermore, the study revealed students did not have devices such as smartphones or computers, and there was little to no support from parents due to their lack of knowledge of online learning.

Adnan and Anwar (2020) examined the effectiveness and challenges of online learning in Pakistan higher learning institutions. They surveyed both undergraduate and postgraduate students. Major challenges identified from the study were lack of internet access, absence of adequate interaction with students and lecturers, and ineffective technology. In addition, students from disadvantaged backgrounds and rural areas had limited access to high-speed internet. Students faced challenges despite online learning being the best response to the current lockdown and social distancing measures in place for higher learning institutions. It is worth noting that students in higher learning institutions in developing countries seem to face challenges shared across the globe. 
Laksana (2021) examined the views of 97 students regarding their perceptions of online learning during the COVID-19 pandemic. The study showed that the repercussions of obliging students to use an online platform for TLA are financial support, limited access to resources, and lack of skill. Furthermore, although $66 \%$ of users have access to a mobile device for online learning, only $32 \%$ indicated they had internet coverage or facilities available. Additionally, the study showed that less than half of the student population had the necessary online learning skills. Further analysis revealed that students lacking these skills experienced difficulties when attempting online assessments. In essence, students from the target population indicated that the lack of gadgets, the high cost of data, and limited internet access hindered their TLA experience.

Wintachai et al. (2021) conducted a study in Thailand that examined how developing and middle-income countries have transitioned to online learning amid the COVID-19 pandemic. They found that students from middle- and lower-income households are more likely to be negatively affected by the shift in TLA delivery. The authors suggested that these students should be afforded government support. A study conducted by Malhotra and Bhatia (2021) showed that 23 educators undergoing an online course in India expressed feelings of unpreparedness and psychological stress. Additionally, the participants of the study found the cost of online learning to be a challenge. Similar findings were reported by Abbasi et al. (2020), who examined how students perceived online learning during the COVID-19 pandemic in Pakistan among 382 students. The findings showed that the majority of the students had a negative perception of online learning due to underpreparedness of the country's infrastructure for the shift to online TLA. Additionally, most students indicated that they were underprepared due to the incompatibility of their mobile devices for online learning.

Ali (2020) suggested that LMSs such as Moodle placed students at a disadvantage because of their limited knowledge of basic computer skills as well as of various LMSs. This disparity is due to the issue of equity that was identified in the study. Many respondents showed that internet access and affordability was a concern and hindered their ability to succeed. In addition, the LMS Moodle was not mobile friendly, which posed a challenge to educators and students. Pal and Vanijja (2020) explored the usability of the MS Teams LMS on different devices during the COVID-19 pandemic among 1,595 students in India. Respondents indicated that although a digital divide exists in developing countries, the use of MS Teams is user friendly on both mobile device and laptop, which suggests the application is easily accessible and navigated on any device.

The preceding paragraphs have demonstrated mixed empirical findings on students' perceptions of online and blended learning during the COVID-19 pandemic. Furthermore, results from developing countries were different from those in developed countries, with students in developed countries viewing the transition positively.

\section{Methodology}

This study adopted the quantitative method to explore Cost and Management Accounting students' perceptions of the impact of the COVID-19 pandemic on teaching and learning. Primary data were sourced from online questionnaires administered via MS Teams to undergraduate students. The target population for this study was the undergraduate students enrolled in the Cost and Management Accounting modules during the first semester of 2020, comprising 430 students. A convenience sampling technique was employed to select the participants for the study, resulting in a final sample of 191 students (response rate of 56\%). To ensure the validity of the instrument, a pilot study was conducted to confirm there was no ambiguity in the questions asked and that the questionnaire was reliable and valid to gather data for the main study. The Cronbach's alpha coefficient was also used to measure the reliability of the questionnaire. An overall reliability score for each section exceeded the recommended value of 0.70 , indicating that the study was reliable. Anonymity and confidentiality of the participants were maintained throughout the study. After cleaning and organizing the collected data, descriptive analysis was used to examine and demonstrate survey participants' attitudes toward the impact of the COVID-19 pandemic on their teaching and learning. The Statistical Package for Social Sciences version 26.0 was used for the data analysis.

\section{Results and Discussion}

The following section provides an analysis and discussion of the results obtained in this study. The investigation was aligned with the study's aim and objectives, which was to explore the impact of COVID-19 on the Cost and Management Accounting students at DUT. The analysis was drawn from the online questionnaires administered to 430 students enrolled in the National Diploma programme for the 2020 academic period. However, because of numerous challenges encountered during the collection stage of the data, such as the lack of distribution of mobile data by HEIs, connectivity issues due to poor network coverage, and the unavailability of smart devices, a concerning response rate of $56 \%$ was achieved. This response rate was considered satisfactory given the limitations brought about by the pandemic, which were beyond the researchers' control. 
The following analysis will be discussed.

Table 2. Cross tabulation of blended learning demographics

\begin{tabular}{|c|c|c|c|c|c|c|c|c|c|c|c|c|c|}
\hline & \multirow[t]{2}{*}{ Age } & \multicolumn{2}{|l|}{$18-19$} & \multicolumn{2}{|l|}{$20-22$} & \multicolumn{2}{|l|}{$23-25$} & \multicolumn{2}{|l|}{$29-31$} & \multicolumn{2}{|l|}{$32+$} & \multicolumn{2}{|l|}{ Total } \\
\hline & & Count & $\begin{array}{l}\% \text { of } \\
\text { Total }\end{array}$ & Count & $\begin{array}{l}\% \text { of } \\
\text { Total }\end{array}$ & Count & $\begin{array}{l}\% \text { of } \\
\text { Total }\end{array}$ & Count & $\begin{array}{l}\% \text { of } \\
\text { Total }\end{array}$ & Count & $\begin{array}{l}\% \text { of } \\
\text { Total }\end{array}$ & Count & $\begin{array}{l}\% \text { within } \\
\text { Age }\end{array}$ \\
\hline \multirow[t]{2}{*}{ Gender } & Female & 53 & $27,70 \%$ & 55 & $28,80 \%$ & 14 & $7,30 \%$ & 8 & $4,20 \%$ & 0 & $0,00 \%$ & 130 & $68,10 \%$ \\
\hline & Male & 17 & $8,90 \%$ & 25 & $13,10 \%$ & 16 & $8,40 \%$ & 1 & $0,50 \%$ & 2 & $1,00 \%$ & 61 & $31,90 \%$ \\
\hline Total & & 70 & $36,60 \%$ & 80 & $41,90 \%$ & 30 & $15,70 \%$ & 9 & $4,70 \%$ & 2 & $1,00 \%$ & 191 & $100,00 \%$ \\
\hline $\begin{array}{l}\text { Current } \\
\text { Device used } \\
\text { for blended }\end{array}$ & Laptop & 2 & $2,90 \%$ & 6 & $7,50 \%$ & 1 & $0,00 \%$ & 0 & $0,00 \%$ & 0 & $0,00 \%$ & 9 & $4,70 \%$ \\
\hline \multirow[t]{3}{*}{ TLA } & Smartphone & 64 & $91,40 \%$ & 69 & $86,30 \%$ & 27 & $90,00 \%$ & 7 & $100,00 \%$ & 2 & $11,00 \%$ & 169 & $88,50 \%$ \\
\hline & Tablets & 3 & $4,30 \%$ & 5 & $6,30 \%$ & 2 & $6,70 \%$ & 2 & $22,20 \%$ & 0 & $0,00 \%$ & 12 & $6,30 \%$ \\
\hline & $\begin{array}{l}\text { Computer } \\
\text { (PC) }\end{array}$ & 1 & $1,40 \%$ & 0 & $0,00 \%$ & 0 & $0,00 \%$ & 0 & $0,00 \%$ & 0 & $0,00 \%$ & 1 & $0,50 \%$ \\
\hline Total & & 70 & 100 & 80 & 100.1 & 30 & 96.7 & 9 & 122.20 & 2 & 11 & 191 & $100,00 \%$ \\
\hline
\end{tabular}

Table 2 shows the distribution of age and gender among the respondents who participated in this study. Based on the results, $130(68.1 \%)$ of the respondents were women and 61 (31.9\%) were male indicating that most of the respondents were female. Out of the total 191 respondents, 70 (36.6\%) of the respondents were under 20 years of age, 80 (41.9\%) were under 23 years of age, and $30(15.7 \%)$ were under 26 years of age, while nine $(4.7 \%)$ were under 32 years of age and only two (1\%) of the respondents were over 32 years of age. Thus, all the respondents were young adults. Larkin (2019) asserted that young adults adapt better to blended online learning.

The demographic information shown in Table 1 also revealed that $169(88.5 \%)$ of the respondents used their smartphones for blended learning across all age groups, whereas a few respondents, nine (4.7\%), utilized laptops, 12 $(6.3 \%)$ utilized tablets, and one $(0.5 \%)$ used a computer as a device for blended learning within the age of 25 years. These results show that the majority of the respondents between the ages of 18 and 22 utilized smartphones. The results also support the findings of Agormedah et al. (2020) in Ghana that students used smartphones for online learning during COVID-19. The study further elaborated that students could effectively use smartphones for online learning, which could be attributed to the computer literacy courses offered.

However, Laksana (2021) found that although $66 \%$ of the respondents used smartphones for online learning, less than half the population could utilize technology effectively. Also, Abbasi et al. (2020) found similar results in a study conducted in Pakistan, where 382 students, at a medical college, showed that mostly mobile devices were used for online learning. Consequently, students have a negative perception of e-learning due to the lack of skills and infrastructure, which may be due in part to the country's inability to fully embrace e-learning due to circumstances. This showed that students struggled with the use of mobile devices for online learning. 
Table 3. Preferred service/network providers according to the students' residential areas

\begin{tabular}{|c|c|c|c|c|}
\hline Service Provider & & Rural & Urban & Total \\
\hline \multirow[t]{2}{*}{ Telkom } & Count & 19 & 19 & 38 \\
\hline & $\%$ within Indicate your network provider & $50,0 \%$ & $50,0 \%$ & $100,0 \%$ \\
\hline \multirow[t]{2}{*}{ Cell C } & Count & 10 & 27 & 37 \\
\hline & $\%$ within Indicate your network provider & $27,0 \%$ & $73,0 \%$ & $100,0 \%$ \\
\hline \multirow[t]{2}{*}{ MTN } & Count & 17 & 40 & 57 \\
\hline & $\%$ within Indicate your network provider & $29,8 \%$ & $70,2 \%$ & $100,0 \%$ \\
\hline \multirow[t]{2}{*}{ Vodacom } & Count & 14 & 40 & 54 \\
\hline & $\%$ within Indicate your network provider & $25,9 \%$ & $74,1 \%$ & $100,0 \%$ \\
\hline \multirow[t]{2}{*}{ Telkom + Cell C } & Count & 1 & 0 & 1 \\
\hline & $\%$ within Indicate your network provider & $100,0 \%$ & $0,0 \%$ & $100,0 \%$ \\
\hline \multirow[t]{2}{*}{ Telkom + MTN } & Count & 1 & 0 & 1 \\
\hline & $\%$ within Indicate your network provider & $100,0 \%$ & $0,0 \%$ & $100,0 \%$ \\
\hline \multirow[t]{2}{*}{ Telkom + Vodacom } & Count & 0 & 1 & 1 \\
\hline & $\%$ within Indicate your network provider & $0,0 \%$ & $100,0 \%$ & $100,0 \%$ \\
\hline \multirow[t]{2}{*}{ MTN + Other } & Count & 1 & 1 & 2 \\
\hline & $\%$ within Indicate your network provider & $50,0 \%$ & $50,0 \%$ & $100,0 \%$ \\
\hline Total & & 63 & 128 & 191 \\
\hline
\end{tabular}

Table 3 shows the correlation between the service/network providers and the residential areas of the respondents when accessing online platforms. The results showed that the majority (57) of the respondents used MTN; of the respondents, 40 resided in an urban area and 17 lived in rural areas. The second preferred service provider was Vodacom, with 54 respondents; of these respondents, 40 were located in urban areas and 14 resided in rural areas. The least utilized service providers were Telkom (38) and Cell-C (37). Very few respondents indicated using more than one service provider (5).

Access to the internet is critical to online learning because this is a requirement for students to access the LMSs. Internet access can be influenced by place of residence and the service providers in the area. A study by Adnan and Anwar (2020) in Pakistan concurred that most students do not have access to a reliable internet and struggle with online learning, with students from less developed areas not having the same internet as those from developed areas.

Service providers experience challenges in roaming and handling the traffic escalation imposed on these telecommunications during the pandemic. As a result, connectivity issues still prevail in the digital space, even with the predominant service provider chosen. Moreover, Table 3 shows that the residential challenges associated with connectivity play a significant role in blended TLA. The results showed that most of the respondents, $128(67.0 \%)$, reside in urban areas, whereas $63(33.0 \%)$ reside in rural areas. Based on these results, it is evident that most of the respondents live in urban areas and have adequate infrastructures supporting connectivity.

A study by Wintachai et al. (2021) indicated that a lack of financial support and infrastructure in developing and middle-income countries showed that students are more likely to suffer repercussions from the transition to online learning during the pandemic. Developing and middle-income countries are far less technologically advanced than first world countries are. 


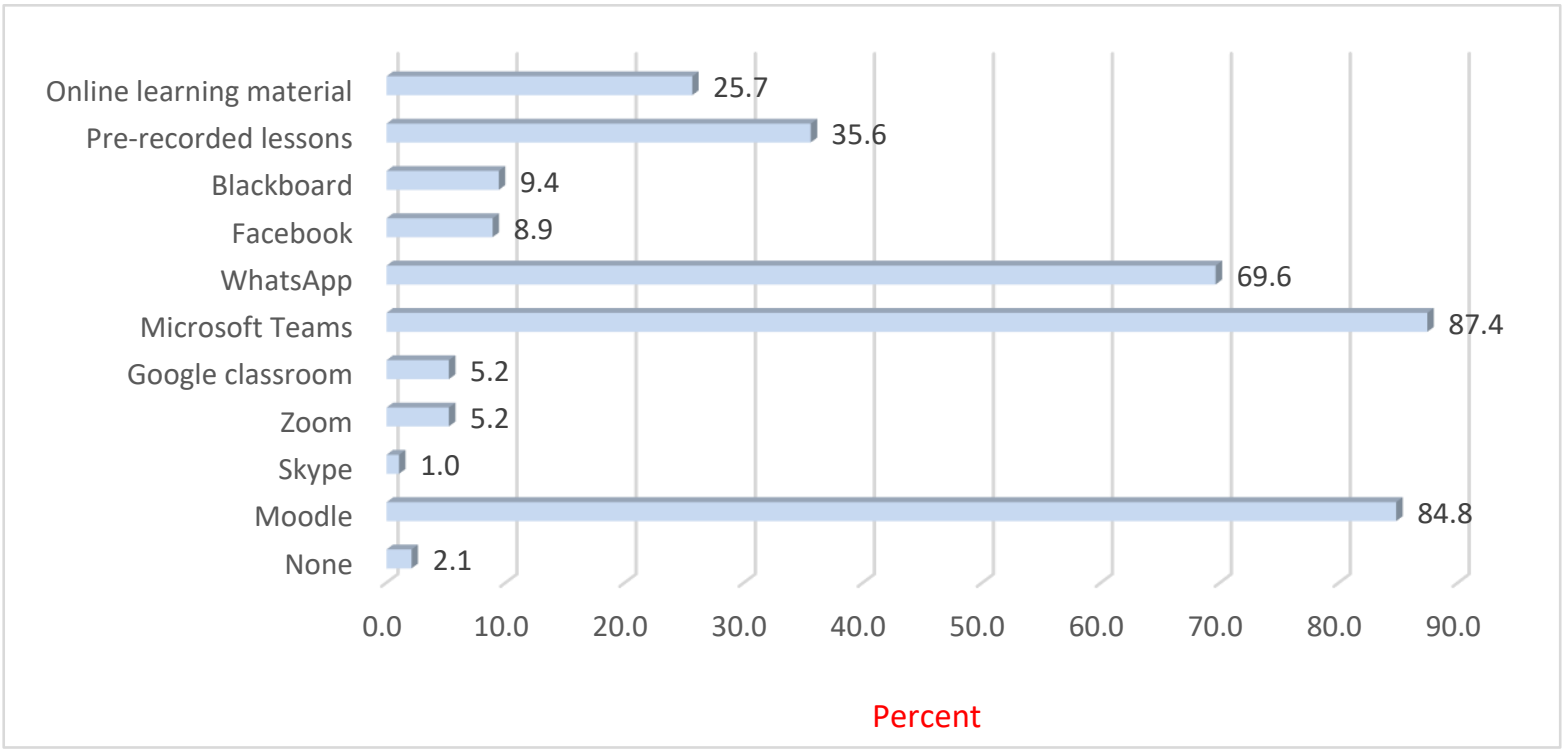

Figure 1. Types of preferred tools utilized for online learning

Figure 1 shows the preferred tools utilized for online learning that were available prior and during the lockdown period. The respondents used multiple devices to support their online learning activities, and the responses were ranked according to their preferences. As reflected in the figure, most respondents (87.4\%) indicated they preferred and utilized MS Teams as a tool for blended learning. Furthermore, $84.8 \%$ of the respondents stated that they used and preferred Moodle to access their TLA activities, whereas a relevant number $(69.6 \%)$ of the respondents revealed that WhatsApp was more suitable for their TLA needs. These results support the recommendation of the World Bank (2020a) because it was evident that the preferred tools to support TLA were MS Teams, Moodle, and WhatsApp. However, a relatively low adoption rate of prerecorded lessons was identified; $35.6 \%$ of the respondents preferred this tool, whereas $25.7 \%$ preferred accessing online materials independently. These results did not concur with the Owen et al. (2019) study, which concluded that learners perceived prerecorded lessons to be more convenient and effective for their blended learning activities. The least preferred tools were identified as Blackboard, Facebook, Google classrooms, and Zoom Skype, and some preferred no tools.

Studies such as Ali (2020) investigated the use of Moodle as an LMS. The study suggested that migrating to blended learning platforms such as MS Teams and Moodle allows users to have more flexibility and self-motivation toward their studies. However, the findings indicated that students lacked the know-how to use the LMS Moodle. Additionally, the study found that the LMSs should be mobile friendly and have more affordable internet access.

Based on a study conducted by Pal and Vanijja (2020), despite the challenges of the digital divide in developing countries, MS Teams is easily navigated and accessed on both a mobile device or a laptop, and despite the difference in size and features across devices, MS Teams was the preferred LMS in the study.

Table 4. Connectivity challenges related to TLA

\begin{tabular}{lllllllllllll}
\hline \multirow{2}{*}{ Level of study } & \multicolumn{2}{l}{ First Year } & \multicolumn{4}{c}{ Second Year } & \multicolumn{4}{c}{ Final Year } & \multicolumn{4}{c}{ Total } \\
& N & Mean & SD & N & Mean & SD & N & Mean & SD & N & Mean & SD \\
\hline Data & 90 & 4,17 & 0,997 & 55 & 3,73 & 1,224 & 42 & 3,74 & 3,601 & 187 & 3,92 & 1,182 \\
Network & 85 & 3,93 & 1,1 & 53 & 3,81 & 1,039 & 40 & 3,37 & 2,837 & 179 & 3,74 & 1,127 \\
Device & 83 & 4,04 & 1,194 & 52 & 3,83 & 1,098 & 37 & 3,41 & 3,828 & 172 & 3,83 & 1,214 \\
\hline
\end{tabular}

Table 4 indicates the various connectivity challenges affecting TLA across all levels of studies, including data, network, and device. In the table, the data category reflects the highest mean score across all levels of study. The first-year students indicated the highest mean score of 4.17 , whereas the final year showed a score of 3.74 , followed closely by the second year with a score of 3.73. These scores concur with those of Mhlanga and Moloi (2020) and Owusu-Fordjour et al. (2020), who found that data were a common challenge among students in different countries. Further, the results agree with the findings of the Agormedah et al. (2020) study in that most students were unable to 
purchase data. The use of data is imperative for students during online learning. Also, Wintachai et al. (2021) showed agreement that students without financial stability are more likely to suffer the consequences of online learning during the pandemic.

The network category highlights that the first-year students scored the highest average score of 3.93, whereas the second-year students showed a score of 3.81, and the least score of 3.37 was indicated by the final-year students. These findings show that the respondents agreed that connectivity issues associated with the network caused TLA challenges for them. The results concurred with those of Adnan and Anwar (2020), Laksana (2021), and Ali (2020), who showed similar network challenges in developing and middle-income countries such as South Africa.

The device category shows that the first-year students scored the highest mean of 4.04, followed by the second-year students, who reflected the second highest mean score of 3.83, and the least mean score, which was 3.41, was derived from the third-year students. These results concur with those of Abbasi et al. (2020) and Laksana (2021), who found that devices such as mobile phones or smartphones, although used by the majority of the respondents, created challenges for online learning.

Table 5. Challenges affecting students' online learning amid the COVID-19 pandemic

\begin{tabular}{|c|c|c|c|c|c|}
\hline Statements & $\begin{array}{l}\text { Strongly } \\
\text { Disagree }\end{array}$ & Disagree & Neutral & Agree & $\begin{array}{l}\text { Strongly } \\
\text { Agree }\end{array}$ \\
\hline General anxiety about COVID-19 & $4,2 \%$ & $5,8 \%$ & $14,7 \%$ & $37,7 \%$ & $37,7 \%$ \\
\hline My personal health issues & $5,2 \%$ & $19,9 \%$ & $29,3 \%$ & $27,7 \%$ & $17,8 \%$ \\
\hline Communication with fellow students & $3,7 \%$ & $11,5 \%$ & $31,9 \%$ & $37,2 \%$ & $15,7 \%$ \\
\hline My physical workspace & $7,3 \%$ & $12,6 \%$ & $20,9 \%$ & $34,0 \%$ & $25,1 \%$ \\
\hline My own internet connectivity & $11,5 \%$ & $11,5 \%$ & $20,9 \%$ & $26,2 \%$ & $29,8 \%$ \\
\hline Keeping a regular schedule & $6,8 \%$ & $14,7 \%$ & $24,1 \%$ & $30,9 \%$ & $23,6 \%$ \\
\hline Access to technology-based tools to learn effectively & $9,4 \%$ & $16,8 \%$ & $19,4 \%$ & $33,5 \%$ & $20,9 \%$ \\
\hline Social isolation & $5,2 \%$ & $10,5 \%$ & $28,3 \%$ & $39,3 \%$ & $16,8 \%$ \\
\hline Disturbances (noise pollution) & $2,6 \%$ & $6,3 \%$ & $15,2 \%$ & $28,3 \%$ & $47,6 \%$ \\
\hline Lack of online training & $5,2 \%$ & $9,4 \%$ & $13,6 \%$ & $34,0 \%$ & $37,7 \%$ \\
\hline Financial difficulties & $3,1 \%$ & $5,2 \%$ & $12,6 \%$ & $36,1 \%$ & $42,9 \%$ \\
\hline Family obligations & $2,6 \%$ & $6,8 \%$ & $22,0 \%$ & $34,0 \%$ & $34,6 \%$ \\
\hline Depression & $4,7 \%$ & $16,8 \%$ & $21,5 \%$ & $27,2 \%$ & $29,8 \%$ \\
\hline Stress & $4,2 \%$ & $5,2 \%$ & $16,8 \%$ & $27,7 \%$ & $46,1 \%$ \\
\hline Providing information and updates on current affairs & $5,8 \%$ & $6,8 \%$ & $17,8 \%$ & $58,1 \%$ & $11,5 \%$ \\
\hline $\begin{array}{l}\text { Adjusting the academic calendar to accommodate and } \\
\text { support the completion of the academic year }\end{array}$ & $4,2 \%$ & $6,8 \%$ & $15,2 \%$ & $55,0 \%$ & $18,8 \%$ \\
\hline Considering students emotional health & $18,8 \%$ & $19,9 \%$ & $25,1 \%$ & $30,9 \%$ & $5,2 \%$ \\
\hline
\end{tabular}

Table 5 shows both internal and external challenges affecting online learning approaches during the COVID-19 pandemic. Based on the table, $79 \%$ of the respondents were in agreement that financial difficulties had an impact on their online learning experience. However, $12.6 \%$ of the respondents were neutral toward the statement, which indicated they neither agreed nor disagreed with the statement. A few of the respondents $(8.3 \%)$ did not agree with the statement, which implied they did not see any significant role associated with financial difficulties toward remote learning. Studies conducted by Ali (2020), Laksana (2021), Wintachai et al. (2021), and Adnan and Anwar (2020) also found that developing and middle-income countries struggle with the migration to an online platform due to lack of resources and finances in households.

The majority of the respondents $(75.6 \%)$ indicated that disturbances imposed a great challenge to their online learning, whereas $75.38 \%$ indicated that they experienced anxiety about COVID-19 during their online learning experience. Because of the unprecedented nature of this disease among human beings, it was evident that it caused anxiety and distress. These findings concurred with those of Malhotra and Bhatia (2021), who found that learners were unprepared for the transition to online learning on a psychological level. Also, the high cost associated with access to and 
maintenance of online learning was shown as one of the triggers of stress and anxiety during the transition to online learning. Anxiety and stress are normally interchangeable and can be caused by a threat trigger. The majority of the respondents $(73.8 \%)$ indicated that stress had an impact on their online learning experience. Similar to the stress factor, the majority of the respondents (73.8\%) expressed that adjusting the academic calendar to complete the assessments affected their online learning experience.

The majority of the respondents (71.7\%) indicated that lack of online training caused an impact on their online learning experience. The results were in agreement with those of Agormedah et al.'s (2020) study in Ghana, where students had never been introduced to e-learning and did not receive any e-learning training. It should be noted that students are introduced to the institution LMS, Moodle, in the first year. Despite the respondents being from all levels of study, the majority of students' lack of training was necessary, which is supported by the findings of Laksana (2021) and Ali (2020).

\section{Conclusion and Recommendations}

This paper contributes to the ongoing research on the COVID-19 pandemic by identifying the factors and challenges students face in TLA and the shift from face-to-face and blended learning to remote learning. Such a process covers factors affecting students in a developing economy that have not been previously examined; therefore, the findings represent a novel contribution for university policymakers to review and utilize to ensure the successful implementation of an online learning system. This research's findings are based on empirical evidence, which identifies the factors that affected students' learning during the pandemic and endorses other studies conducted around the challenges students face in the transition to online remote learning.

Based on the results, the main challenges that impede learning remotely during the pandemic included connectivity due to devices and network. Furthermore, anxiety about COVID-19 was identified as another significant factor that led to mental stress, which impacted online learning. Considering that remote learning has become the new norm, and students are expected to adjust from a traditional to a remote learning environment, university managers can benefit from this study's findings by using them as a guideline to improve the online learning system. The manner in which we respond to the challenges brought about by the onset of the pandemic and the actions we take now will have a profound impact on the future of education.

Nonetheless, the study provided riveting results that were limited to the perceptions derived from the participants of this study and cannot be generalized in a much broader spectrum. These results also call for universities, governments, and other stakeholders to collaborate on developing and maintaining effective online solutions beyond the pandemic era. Future studies should consider evaluating students' satisfaction with pedagogies implemented to sustain online learning.

\section{References}

Agormedah, E. K., Henaku, E. A., Ayite, D. M. K., \& Ansah, E. A. (2020). Online Learning in Higher Education during COVID-19 Pandemic: A case of Ghana. Journal of Educational Technology \& Online Learning, 3(3), 183-210. https://doi.org/10.31681/jetol.726441

Abbasi, S., Ayoob, T., Malik, A., \& Memon, S. I. (2020). Perceptions of students regarding E-learning during Covid-19 at a private medical college. Pakistan Journal of Medical Sciences. https://doi.org/10.12669/pjms.36.COVID19-S4.2766

Adnan, M., \& Anwar, K. (2020). Online learning amid the COVID- 19 pandemic: students' perspectives. Journal of Pedagogical Sociology and Psychology, 2(1), 45-51. https://doi.org/10.33902/JPSP.2020261309

Ali, W. (2020). Online and remote learning in higher Education Institutes: a necessity in light of Covid- 19 pandemic. Higher education studies, 10(3), 16-25. https://doi.org/10.5539/hes.v10n3p16

Barab, S. A., Barnett, M., Yamagata-Lynch, L., Squire, K., \& Keating, T. (2002). Using Activity Theory to Understand the Systemic Tensions Characterising a Technology-Rich Introductory Astronomy Course. Mind, Culture, and Activity, 9(2), 76-107. https://doi.org/10.1207/S15327884MCA0902_02

Durban University of Technology (DUT). (2020). Faculty of Accounting and Information Teaching Framework. (2020).

Giovannella, C. (2021). Effect induced by the Covid-19 pandemic on students' perception about technologies and distance learning. In Ludic, Co-design and tools supporting smart learning ecosystems and smart education, 105-116. https://doi.org/10.1007/978-981-15-7383-5_9 
Karasavvidis, I. (2009). Activity Theory as a theoretical framework for the study of blended learning: a case study. In Proceedings of the 6th International Conference on Networked Learning, 195-202

Laksana, D. N. L. (2021). Implementation of online learning in the pandemic covid-19: Student perception in areas with minimum internet access. Journal of Education Technology, 4(4), 502-509. https://doi.org/10.23887/jet.v4i4.29314

Larkin, P. B. (2019). An evaluation of student perceptions of learning environments across fully online versus blended course delivery formats. https://doi.org/10.18297/etd/3200

Malhotra, L., \& Bhatia, H. K. (2021). From Walls to Clouds: SWOCs of Online Learning from Voices of Prospective Teacher Educators in India in Response to Covid-19. The Online Journal of Distance Education and e-Learning, 9(1), 92-105.

Mhlanga, D., \& Moloi, T. (2020). COVID-19 and the digital transformation of education: what are we learning on 4IR in South Africa. Education Sciences, 10. https://doi.org/10.3390/educsci10070180

Muthuprasad, T., Aiswarya, S., Aditya, K. S., \& Girish, K. Jha. (2020). Students' perception and preference for online education in India during COVID-19 pandemic. https://doi.org/10.2139/ssrn.3596056

Owston, R., York, D. N., \& Malhotra, T. (2019). Blended learning in large enrolment courses: Student perceptions across four different instructional models. Australasian Journal of Educational Technology, 35, 29-45. https://doi.org/10.14742/ajet.4310

Owusu-Fordjour, C., Koomson, C. K., \& Hanson, D. (2020). The impact of COVID-19 on learning the perspective of the Ghanaian student. European Journal of Education Studies, 7(3), 88-101.

Pal, D., \& Vanijja, V. (2020). Perceived usability evaluation of Microsoft Teams as an online learning platform during COVID-19 using system usability scale and technology acceptance model in India. Children and youth services review, 119, 105535. https://doi.org/10.1016/j.childyouth.2020.105535

Scanlon, E., \& Issroff, K. (2005). Activity Theory and Higher Education: evaluating learning technologies. Journal of Computer Assisted learning, 21, 430-439. https://doi.org/10.1111/j.1365-2729.2005.00153.x

Schleicher, A. (2020). The impact of COVID-19 on education insights from education at a glance 2020.

Wintachai, J., Khong, T. D. H., \& Saito, E. (2021). COVID-19 as a game changer in a Thai university: a self-reflection. Practice, 1-7. https://doi.org/10.1080/25783858.2020.1833233

World Bank. (2020a). Guidance note: remote learning and COVID- 19. http://documents1.worldbank.org/curated/en/531681585957264427/pdf/Guidance-Note-on-Remote-Learning-an d-COVID-19.pdf

World Bank. (2020b). Remote learning and COVID-19 The use of educational technologies at scale across an education system as a result of massive school closings in response to the COVID-19 pandemic to enable distance education and online learning. Available: http://documents1.worldbank.org/curated/en/531681585957264427/pdf/Guidance-Note-on-Remote-Learning-an d-COVID-19.pdf

\section{Copyrights}

Copyright for this article is retained by the author(s), with first publication rights granted to the journal.

This is an open-access article distributed under the terms and conditions of the Creative Commons Attribution license (http://creativecommons.org/licenses/by/4.0/). 